\title{
PEMBERDAYAAN PEREMPUAN PADA KELOMPOK SALMA BATIK DI DUSUN MALON KECAMATAN GUNUNGPATI KOTA SEMARANG
}

\author{
${ }^{1}$ Haryani, ${ }^{2}$ Liliek Desmawati \\ 1,2 Jurusan Pendidikan Luar Sekolah, FIP, Universitas Negeri Semarang \\ Gedung A2 Kampus Sekaran Gunungpati Telp. 8508019 Semarang 50229 \\ haryanimardi@gmail.com
}

\begin{abstract}
Abstrak
Tujuan penelitian ini adalah mendeskripsikan proses pemberdayaan perempuan pada kelompok Salma Batik di Dusun Malon dan faktor pendukung dan penghambat dalam pemberdayaan perempuan pada kelompok Salma Batik di Dusun Malon, Kecamatan Gunungpati, Kota Semarang. Penelitian ini menggunakan pendekatan kualitatif. Teknik pengumpulan data berupa observasi, wawancara, dan dokumentasi. Keabsahan data dengan menggunakan triangulasi. Teknik analisis data melalui tahap reduksi data, penyajian data, dan penarikan kesimpulan. Simpulan penelitian ini adalah program pemberdayaan perempuan pada kelompok Salma Batik meliputi tahap perencanaan, pelaksanaan, dan evaluasi; faktor pendukung meliputi, adanya tanggapan positif dari masyarakat, dukungan dari berbagai pihak baik pemerintah desa maupun pihak lainnya seperti PT Indonesia Power dan Unnes, SDA dan SDM yang mendukung; faktor penghambat meliputi, segi permodalan, sikap pesimis anggota (rendahnya motivasi), dan kurangnya segi pemasaran. Saran yang diberikan dalam penelitian ini, perlu adanya pendampingan yang intensif kepada kelompok batik setelah mereka terbentuk agar tujuan pemberdayaan membentuk masyarakat yang mandiri dapat tercapai.
\end{abstract}

Kata Kunci: Pemberdayaan, Perempuan, Kelompok Batik

\begin{abstract}
The purposes of this study are to describe women empowering process in Salma Batik group in Malon Hamlet, and to describe the supporting and inhibiting factors in women empowerment in Salma Batik group in Malon Hamlet, Gunungpati Subdistrict, Semarang City. This study uses a qualitative approach. The data collection techniques are observation, interviews, and documentation. Data validity uses triangulation. Data analysis techniques go through the stages of data reduction, data presentation, and conclusion. The conclusions of this study are that the women's empowerment program in Salma Batik group covering the stages of planning, implementation and evaluation. The supporting factors include positive responses from the community, and getting support from various parties, both the village government and other parties such as PT Indonesia Power and Semarang State University (Unnes), nature resources (SDA), and supporting human resources (SDM). The inhibiting factors include capital aspects, members' pessimistic attitude (low motivation), and lack of marketing aspects. Suggestions given in this study is to provide intensive assistance to Batik groups after they are formed so that the empowerment goal to form an independent community can be achieved.
\end{abstract}

Keywords: Empowerment, Women, Batik Group

\section{PENDAHULUAN}

Perempuan sebagai bagian dari pembangunan nasional tersebut juga memiliki peranan penting. Perempuan memiliki sejumlah potensi, yang mana apabila dikelola dengan baik maka akan memberikan dampak yang sangat besar. Persentase jumlah kaum perempuan pun jauh lebih tinggi apabila dibandingkan dengan jumlah kaum laki-laki, akan tetapi pada kenyataannya tingkat partisipasi kerja perempuan di Indonesia masih tergolong rendah apabila dibandingkan dengan tingkat kerja laki-laki. Berdasarkan data (BPS, 2017) diketahui bahwa proyeksi penduduk Kabupaten/Kota Provinsi Jawa Tengah 2010-2025 jumlah 
penduduk perempuan angkatan kerja mencapai 11.707.583 jiwa (Tabel Jumlah Penduduk Menurut Kelompok Umur dan Jenis Kelamin tahun 2017). Dari jumlah tersebut kaum perempuan dapat menjadi pelaku pembangunan ekonomi dalam menggerakkan masyarakat untuk memerangi kemiskinan. Strategi untuk memperbaiki perekonomian kaum perempuan bersama diperlukan untuk meningkatkan kesejahteraan masyarakat secara keseluruhan.

Aswiyati (2016: 3) mengungkapkan bahwa usaha meningkatkan peran dan sumbangan perempuan dalam pembangunan, termasuk menunjang perekonomian keluarga, ternyata perempuan Indonesia menyadari sepenuhnya untuk meningkatkan taraf hidup dan kemajuan, sehingga terpenuhi kebutuhan spiritual dan materil. Salah satu upaya yang dapat dilakukan untuk meningkatkan posisi tawar perempuan dalam meningkatkan perannya dalam pembangunan nasional adalah dengan pemberdayaan. Pratama (2013: 12) dalam konteks pemberdayaan perempuan, perempuan harus memiliki kesadaran untuk terlibat sendiri dalam kegiatan-kegiatan yang dilakukan. Partisipasi disini juga berarti perempuan harus ikut andil dalam setiap pengambilan keputusan karena nantinya mereka sendiri yang melakukan. Partisipasi berfokus pada bagaimana mereka diberdayakan dan peran apa yang mereka mainkan setelah mereka menjadi bagian dari kelompok yang diberdayakan. Sumodiningrat (2000) dalam Widjajanti (2010: 528) menjelaskan bahwa pemberdayaan tidak bersifat selamanya, melainkan sampai target masyarakat mampu untuk mandiri, dan kemudian dilepas untuk mandiri, meskipun dari jauh tetap dipantau agar tidak jatuh lagi. Sedangkan menurut Rifa'i (2008: 40) menjelaskan bahwa pemberdayaan itu terjadi melalui beberapa tahap. Pertama, setiap orang mengembangkan kesadaran awal sehingga mereka dapat mengambil tindakan untuk memperbaiki kehidupannya dan memperoleh pelbagai keterampilan yang memungkinkan mereka melaksanakannya. Kedua, melalui pengambilan tindakan, mereka mengalami keberdayaan dan kepercayaan dirinya meningkat. Ketiga, karena adanya pertumbuhan keterampilan dan kepercayaan, setiap orang bekerja sama berusaha mempengaruhi keputusan dan sumberdaya yang mengakibatkan kesejahteraannya.

Menurut UU No. 20 Tahun 2008 tentang prinsip dan tujuan pemberdayaan, pemberdayaan bertujuan dalam rangka meningkatkan ekonomi kerakyatan agar dapat meningkatkan pendapatan dan kesejahteraan masyarakat serta memperluas lapangan pekerjaan untuk pengentasan rakyat dari permasalahan kemiskinan. Pemberdayaan perempuan memiliki bidang garapan yang luas. Dusun Malon merupakan kampung tematik yang terletak di Kelurahan Gunungpati Kecamatan Gunungpati Kota Semarang terkenal dengan julukan "Kampoeng Alam Malon" memiliki luas wilayah 50,5 Ha yang sebagian besar wilayahnya cenderung digunakan sebagai lahan pertanian sawah dan tegalan. Kepadatan penduduk di Dusun Malon mencapai 376 jiwa yang terdiri atas laki-laki sebanyak 193 jiwa dan perempuan sebanyak 183 jiwa. Masyarakat sehari-hari menghabiskan waktunya untuk mengolah sawah maupun kebun yang berada di desa. Tidak dapat dipungkiri, dominasi yang bekerja dalam sebuah keluarga adalah laki-laki karena tuntutan kewajiban dan perannya sebagai kepala rumah tangga yang bertanggung jawab atas semua aspek dalam keluarga termasuk perekonomian keluarga. Namun pada masyarakat industri modern sekarang ini telah banyak perempuan yang bekerja. Perempuan berhak memasuki pasaran untuk memperoleh pekerjaan guna mengembangkan segala potensi dalam dirinya secara optimal. 
Selain itu, perempuan yang sudah berkeluarga di Dusun Malon mayoritas adalah ibu rumah tangga. Berdasarkan intensitas waktu yang dimiliki ibu rumah tangga memiliki intensitas waktu yang lebih tinggi dari pada ibu yang bekerja di luar rumah. Dalam sebuah penelitian yang dikutip oleh Marzuki (2010: 46) dalam Nugroho (2017: 148) tentang perempuan di perdesaan, pinggiran maupun perkotaan menyatakan bahwa "intensitas waktu perempuan di rumah tidak banyak dimanfaatkan untuk hal-hal positif. Kebiasaan merumpi masih menjadi hal yang menyenangkan dibanding dengan kegiatan lain yang lebih bermanfaat". Hal tersebut akan memberikan dampak pada partisipasi dan akses dari perempuan untuk mengembangkan potensi diri. Sehingga keberdayaan masyarakat khususnya perempuan yang dimaksud bukan serta merta gaji tinggi yang diperoleh setelah mendapatkan peluang kerja. Namun keberdayaan itu lebih kepada bagaimana perempuan itu memiliki kesempatan untuk mengembangkan diri melalui partisipasi aktif sehingga menumbuhkan konsep diri dan semangat keberdayaan, memiliki modal sosial yang kuat baik dalam bekerja sama dalam sebuah kelompok, membangun kepercayaan sosial (responsibility), menjalin jaringan sesuai yang dibutuhkan.

\section{KAJIAN TEORI}

Prijono dan Pranaka dalam Suryana (2010: 16) menyatakan bahwa; pemberdayaan mengandung dua arti pengertian yang pertama adalah to give power or authority, kedua to give ability to or enable. Pemaknaan pengertian pertama meliputi memberi kekuasaan, mengalihkan kekuatan atau mendelegasikan otoritas kepada pihak yang kurang/belum berdaya. Sedangkan pemaknaan pengertian kedua adalah memberikan kemampuan atau keberdayaan serta memberikan peluang kepada pihak lain untuk melakukan sesuatu.

Berbeda dengan pendapat Pranaka, Sumodiningrat dalam Suryana (2010: 17) menyampaikan bahwa pemberdayaan yang dimaksud adalah memberi "daya" bukanlah "kekuasaan". Barangkali istilah yang paling tepat adalah "energize" atau "memberi energi". Pemberdayaan adalah memberi energi agar yang bersangkutan mempu untuk bergerak secara mandiri. Berkenaan dengan pemaknaan konsep pemberdayaan masyarakat, Winarni (2004) dalam Suryana (2010: 18) mengungkapkan bahwa inti dari pemberdayaan adalah meliputi tiga hal, yaitu pengembangan (enabling), memperkuat potensi atau daya (empowering), terciptanya kemandirian. Parsons, dkk (Mardikanto \& soebiato, 2012 : 28) menyatakan bahwa pemberdayaan adalah sebuah proses agar setiap orang menjadi cukup kuat untuk berpartisipasi dalam berbagai pengontrolan, dan mempengaruhi, kejadian-kejadian serta lembaga-lembaga yang mempengaruhi kehidupannya. Pemberdayaan menekankan bahwa orang memperoleh keterampilan, pengetahuan, dan kekuasaan yang cukup untuk mempengaruhi kehidupannya dan kehidupan orang lain yang cukup menjadi perhatiannya.

Hal ini diperkuat oleh Journal Busch and Valentine: Empowerment Practice: A Focus on Betteres Women volume 5 No. 1 oleh Guiterrez, DeLois, et al (Affilia, 2000: 83): "basing the helping relationship on collaboration, trust and share power; utilizing small groups; accepting the client's definition of the problem; identifying and building on the client's strengths; raising the client's consciousness of issues of class and power; actively involving 
the client in the change process; teaching specific skills;...experiencing a sense of personal power within the helping relationship; and mobilizing resources or advocating for clients."

Pendapat tersebut menjelaskan bahwa proses pemberdayaan masyarakat merupakan proses membantu individu dalam menyelesaikan permasalahan yang dihadapi dengan mengidentifikasi kekuataan atau potensi individu tersebut serta memberikan kepercayaan dan keterampilan dan juga mengembangkan sumber daya manusia yang ada tanpa mengadili individu yang bersangkutan.

\section{METODE PENELITIAN}

Pendekatan yang digunakan dalam penelitian ini adalah pendekatan kualitatif dengan pokok permasalahan yang dikaji yaitu program pemberdayaan perempuan pada kelompok batik di Dusun Malon Kelurahan Gunungpati Kota Semarang. Subjek penelitian terdiri atas 3 orang anggota kelompok batik dan 2 informan yaitu Ketua Salma Batik dan Kasi Kesejahteraan Sosial Kelurahan Gunungpati. Metode pengumpulan data yang dilakukan oleh peneliti adalah observasi, wawancara dan dokumentasi.

Sumber data dalam penelitian ini berupa sumber data primer dan sumber data sekunder. Data primer didapat dari hasil observasi berupa catatan lapangan dan hasil wawancara peneliti bersama subjek penelitian dan informan penelitian. Sedangkan data sekunder berasal dari dokumen lain relevan dan foto kegiatan membatik. Pengumpulan data dalam penelitian ini dilakukan dengan observasi, wawancara dan dokumentasi. Uji keabsahan data dalam penelitian ini menggunakan triangulasi, yaitu triangulasi sumber dan triangulasi metode. Triangulasi ini dipilih untuk membandingkan dan mengecek derajat kepercayaan suatu informasi yang diperoleh dari anggota dan pengelola kelompok batik dengan menggunakan kisi-kisi yang telah disusun atau disiapkan dalam pengumpulan data. Analisis data yang digunakan dalam penelitian ini yaitu data reduction (reduksi data), data display (penyajian data), dan simpulan / verifikasi.

\section{HASIL DAN PEMBAHASAN}

Pemberdayaan merupakan upaya memanusiakan manusia melalui kegiatan belajar agar terjadi perubahan tingkah laku dengan memaksimalkan potensi-potensi lokal sehingga masyarakat dapat mandiri. Kegiatan kelompok batik di Salma Batik Dusun Malon merupakan salah satu bentuk pemberdayaan perempuan. Tahapan proses pemberdayaan program terdiri atas tahap perencanaan, tahap pelaksanaan, dan tahap evaluasi.

\section{1) Tahap Perencanaan}

Dari pendapat diatas, dapat peneliti lakukan analisis bahwa dalam perencanaan awal terbentuk kelompok batik berawal dari adanya program tematik pemerintah Kota Semarang yang menjadikan Dusun Malon sebagai kampung tematik. Akan tetapi, sebelum menetapkan sebagai kampung tematik, pemerintah sudah melihat potensi di Dusun Malon bahwa banyak masyarakat disana yang sudah memiliki keterampilan membatik. Dasar tentang batik tersebut kemudian dikembangkan oleh masyarakat Malon untuk memajukan daerahnya dengan membentuk kelompok-kelompok batik. Sehingga batik alam malon ini menjadi salah satu produk unggulan di Malon.

\section{2) Tahap pelaksanaan}


Pelaksanaan membatik pada kelompok Salma Batik Dusun Malon dilakukan di kediaman Um, sedangkan kegiatan pelatihan biasanya dilakukan di Padepokan Ilir-ilir. Sistem kerja dilakukan secara berkelompok, dimana setiap kelompok memiliki tugas untuk membuat batik. dengan menggunakan sarana dan alat membatik yang telah disediakan. Ibuibu yang tergabung dalam kelompok batik juga diperkenankan untuk membawa pulang pekerjaan mereka sebagai lemburan. Kegiatan pemberdayaan perempuan pada kelompok Salma Batik terbuka untuk ibu-ibu rumah tangga warga di dusun Malon dan sekitarnya dengan kriteria mereka memiliki kemampuan, mencintai batik dan memiliki komitmen untuk menambah perekonomian keluarga.

Dalam hal pengerjaan batik pun tidak mengganggu karena dilakukan dengan menyesuaikan waktu ibu-ibu setelah selesai mengurus pekerjaan rumah tangga. Hasil penelitian dilapangan juga menunjukkan bahwa adanya kelompok batik ini telah mendidik anggota kelompok batik khususnya ibu rumah tangga untuk mandiri dan tidak bergantung sepenuhnya pada suami dalam memenuhi kebutuhan sehari-hari. Adanya perubahan pola pikir dan cara pandang pada ibu rumah tangga di Dusun Malon telah mendidik anggota kelompok untuk tekun, kreatif dan mengembangkan kemampuan yang dimiliki sesuai dengan bakat yang dimiliki. Aktivitas yang selama ini dilakukan seperti bersendau gurau dengan sesama tetangga, arisan dan perilaku serta sikap yang menyerah pada keadaan telah berubah menjadi kegiatan yang positif berupa keterampilan membatik.

Sedangkan bagi kelompok, adanya program pengembangan batik di Dusun Malon sebagai usaha kecil menengah (UKM) telah mendorong pengembangan ekonomi kerakyatan. Hal tersebut nampak dari jumlah permintaan batik melalui kelompok Salma Batik baik yang datang dari dalam maupun luar kota. Hal ini juga berdampak bahwa Kampung Malon semakin dikenal oleh masyarakat luas. Sedangkan dampak program pemberdayaan membatik juga dirasakan oleh anggota kelompok terutama dalam hal peningkatan pendapatan ekonomi keluarga. Dari pendapat di atas, dapat peneliti lakukan analisis bahwa dalam pelaksanaan pemberdayaan perempuan pada ibu rumah tangga di Dusun Malon telah mengubah pola pikir masyarakat Malon pada umumnya, yang selama ini mereka menganggap bahwa perempuan merupakan manusia yang hanya bergantung pada lelaki terutama dari sisi pendapatan. Dengan adanya kelompok batik ini perempuan menjadi lebih berdaya baik secara fisik dan mental

\section{3) Tahap evaluasi}

\section{a. Proses evaluasi}

Evaluasi program pemberdayaan perempuan pada kelompok batik di Dusun Malon ini dilakukan oleh Um selaku ketua kelompok besar, selain itu beliau juga bertindak sebagai ketua di Salma Batik. Menjadi seorang evaluator diharuskan memiliki kemampuan dalam proses membatik. Evaluator menguasai teori dan praktik tentang membatik tersebut. Dimulai dari proses awal sampai akhir menjadi suatu produk batik. Sehingga evaluator dapat menilai proses pemberdayaan yang dilaksanakan, bagaimana pelaksanaannya apakah sesuai dengan perencanan, bagaimana pencapaian dari tujuan yang telah ditentukan. Evaluator akan selalu memantau hasil pelatihan, sejauh mana pencapaian dari pemberdayaan tersebut, dan selalu memberikan motivasi kepada para peserta. 


\section{b. Waktu evaluasi}

Pelaksanaan kegiatan evaluasi proses pemberdayaan perempuan melalui kelompok batik di Dusun Malon ini dilaksanakan pada waktu pertemuan rutin yaitu setiap satu bulan sekali di minggu pertama. Evaluasi ini akan menjadi acuan bagi program ke depannya, dan mengetahui sejauh mana program pelatihan ini berhasil mencapai tujuan yang diharapkan.

c. Aspek yang Dievaluasi

Aspek-aspek yang di evaluasi mencakup proses awal yaitu penyediaan alat dan bahan, proses pelaksanaan membatik, sampai pada tahap akhir berupa produk yang dihasilkan oleh anggota kelompok batik.

Berdasarkan pengamatan yang dilakukan oleh peneliti, faktor yang menjadi pendukung pemberdayaan perempuan pada kelompok Salma Batik di Dusun Malon ini adalah:

\section{1) Tanggapan Warga Masyarakat}

Pemberdayaan di Dusun Malon ini sasarannya adalah para ibu-ibu rumah tangga. Dengan adanya kegiatan ini diharapkan tercipta kemandirian dan kaum wanita menjadi lebih berdaya, mereka tidak lagi sepenuhnya menggantungkan pada suaminya bahkan mereka pun dapat membantu memenuhi kebutuhan sehari-hari. Para perempuan ibu-ibu rumah tangga di Dusun Malon pun sangat antusias dalam mengikuti program pemberdayaan melalui kelompok batik.

\section{2) Pemerintah Desa atau Pihak Terkait Lainnya}

Peran pemerintah desa atau pihak terkait lainnya dalam kegiatan pemberdayaan ini turut serta mendukung kegiatan pemberdayaan kelompok batik guna membantu mewujudkan masyarakat Malon yang mandiri. Salah satu upaya yang dilakukan yaitu menjalin koordinasi yang baik antar elemen terkait.

\section{3) Sumber Daya Manusia dan Sumber Daya Alam}

Dari hasil pengamatan di lapangan ternyata terdapat pula faktor pendukung pemberdayaan yang ketiga yaitu sumber daya manusia di Dusun Malon sudah terbiasa memiliki keterampilan membatik sebelum adanya program kampung tematik dari pemerintah Kota Semarang, sehingga hal tersebut akan lebih mudah dalam hal pengembangan batik menjadi produk unggulan di Malon.

Setiap program pemberdayaan pasti ada faktor pendukung dan penghambatnya. Berdasarkan hasil wawancara dengan subjek dan informan terdapat beberapa kendala yang dihadapi dalam memberdayakan perempuan melalui kelompok batik tersebut, antara lain:

1) Permodalan

Pemberdayaan perempuan melalui kelompok batik di Dusun Malon Kelurahan Gunungpati ini dalam hal pendanaan didanai oleh Pemerintah Kota Semarang yang dalam hal pengembangannya bekerjasama dengan PT Indonesia Power dan Unnes. Anggota kelompok batik ini diberikan bantuan berupa alat-alat membatik, untuk kegiatan produksi setiap hari mereka menggunakan modal sendiri untuk membeli bahan baku.

2) Sikap Pesimis Anggota (rendahnya motivasi)

Motivasi anggota kelompok batik dalam mengikuti kegiatan pemberdayaan tergolong naik turun. Hal tersebut mempengaruhi kehadiran saat proses pemberdayaan berlangsung, sehingga juga mempengaruhi tingkat keberhasilan program. 


\section{3) Pemasaran}

Pemasaran menjadi salah satu kendala yang dikeluhkan oleh para anggota kelompok batik di Dusun Malon. Terkait pemasaran batik alam Malon sejauh ini hanya dengan mengikutsertakan dalam kegiatan bazar atau pameran UMKM, belum ada wadah yang pasti untuk menampung hasil produk batik alam malon. Sehingga diharapkan pihak terkait lainnya untuk ikut serta dalam membantu proses pemasarannya.

\section{SIMPULAN DAN SARAN}

Berdasarkan hasil penelitian dapat dikemukakan bahwa pemberdayaan perempuan pada kelompok Salma Batik di Dusun Malon, Kecamatan Gunungpati, Kota Semarang dilakukan secara bertahap yaitu tahap persiapan, tahap pelaksanaan, dan tahap evaluasi. Keberhasilan program pemberdayaan perempuan dengan adanya kelompok batik ini mendidik masyarakat khususnya ibu rumah tangga untuk mandiri dan tidak bergantung sepenuhnya pada suami dalam membantu memenuhi kebutuhan sehari-hari, adanya perubahan pola pikir dan cara pandang pada ibu rumah tangga di Dusun Malon serta telah mendidik anggota kelompok untuk tekun, kreatif dan mengembangkan kemampuan yang dimiliki sesuai dengan bakat yang dimiliki sehingga mendorong pengembangan ekonomi kerakyatan dan terjadi peningkatan pendapatan ekonomi keluarga.

Faktor pendukung dalam kegiatan pemberdayaan yaitu adanya tanggapan positif dari masyarakat anggota kelompok batik, adanya dukungan dari pemerintah desa dan juga pihak lainnya seperti PT Indonesia Power serta Perguruan Tinggi Universitas Negeri Semarang, serta SDA dan SDM yang mendukung. Sedangkan faktor penghambat dalam kegiatan pemberdayaan yaitu dari segi permodalan sebenarnya tidak terlalu mempengaruhi karena memang kelompok batik juga diberikan bantuan berupa pelatihan dan alat-alat membatik. Akan tetapi walaupun begitu kelompok batik tetap memerlukan akses permodalan untuk pengembangan batik alam Malon, dari segi pemasaran hasil produk batik alam Malon sejauh ini hanya melalui ikut serta di pameran atau bazar, sehingga jika pasar hanya mengandalkan kondisi seperti ini juga akan menghambat kemajuan kelompok batik di Malon. Sehingga dibutuhkan wadah atau ruang untuk menampung produk batik masyarakat Malon. Selain itu motivasi ibu rumah tangga juga dapat menjadi faktor penghambat pada proses pemberdayaan. Hal ini dikarenakan motivasi dari dari masyarakat yang menjadi anggota kelompok batik ini masih naik turun. Tentu hal tersebut mempengaruhi jalannya proses pemberdayaan pada kelompok batik di Dusun Malon.

Berdasarkan kesimpulan hasil penelitian dikemukakan beberapa saran yaitu: Perlu adanya pendampingan yang intensif kepada kelompok batik setelah mereka terbentuk agar tujuan pemberdayaan membentuk masyarakat yang mandiri dapat tercapai; Untuk mengatasi faktor penghambat tentang permodalan diharapkan dapat menjalin kerjasama dengan pihak lain seperti koperasi agar anggota kelompok batik dapat mengembangkan usaha mereka lebih besar; Dalam membantu terkait pemasaran diharapkan Pemerintah Kota Semarang segera merealisasikan pembuatan galeri batik untuk menampung batik produksi masyarakat Malon.

\section{DAFTAR PUSTAKA}


Aswiyati, Indah. (2016). Peran Wanita dalam Menunjang Perekonomian Rumah Tangga Keluarga Petani Tradisional Untuk Penanggulangan Kemiskinan di Desa Kuwil Kecamatan Kalawat. Jurnal Holistik Jurusan Ilmu Sejarah Fakultas Ilmu Budaya Universitas Sam Ratulangi diakses melalui ejournal.unsrat.ac.id.

Busch, Noel Bridget \& Valentine, Deborah. (2000). Empowerment Practice: A Focus on Battered Women. Affilia. 15 (1), 82-95. Diakses melalui http://journals.sagepub.com/.

Mardikanto, Totok \& Soebiato, Poerwoko. (2012). Pemberdayaan Masyarakat Dalam Perspektif Kebijakan Publik (Edisi Revisi). Bandung: Alfabeta.

Moleong, Lexy.J. 2005. Metode Penelitian Kualitatif. Bandung: PT Remaja Rosdakarya.

Moleong, Lexy.J. 2011. Metode Penelitian Kualitatif. Bandung: PT Remaja Rosdakarya.

Nugroho, Rivo. (2017). Keberdayaan Perempuan Pasca Pelatihan Mengolah Sampah bagi Kelompok Pemberdayaan dan Kesejahteraan Keluarga. Jurnal Pendidikan dan Pemberdayaan Masyarakat, 4 (2), 146-156 diakses melalui http://journal.uny.ac.id/index.php/jppm.

Pratama, Crisvi. (2013). Faktor-Faktor Yang Mempengaruhi Keberhasilan Pemberdayaan Perempuan Desa Joho di Lereng Gunung Wilis. Jurnal Kebijakan dan Manajemen Publik, 1 (1), 12-19.

Rifa'i, Achmad. 2008. Pemberdayaan Masyarakat Melalui Pendidikan Nonformal. Semarang: Unnes Press.

Sugiyono. 2012. Metode Penelitian Pendidikan (Pendekatan Kuantitatif, Kualitatif dan $R \& D)$. Bandung: Alfabeta.

Suryana, Sawa. 2010. Pemberdayaan Masyarakat. Semarang: Universitas Negeri Semarang.

Widjajanti, Kesi. (2010). Resource Based View dan Pemberdayaan. Ekobis, 11(2), 527 - 540. 